\title{
Potensi Produksi dan Pengumpulan Biomasa dari Sampah Daun di Kampus Universitas Sam Ratulangi Kleak Manado dengan Kelompok Mahasiswa Perempuan
}

\author{
Julius Pontoh $^{1^{*}}$, Ratna Siahaan ${ }^{2}$ \\ ${ }^{1}$ Program Studi Kimia, Fakultas MIPA, Universitas Sam Ratulangi, Manado. \\ ${ }^{2}$ Program Studi Biologi, Fakultas MIPA, Universitas Sam Ratulangi, Manado. \\ *Penulis korespondensi. Email: pontohjulius@yahoo.com
}

\begin{abstract}
ABSTRAK
Kampus Universitas Sam Ratulangi sebagai ruang perguruan tinggi terdiri dari unsur unsur fisik dan bilogis. Unsur unsur fisik terdiri dari udara, bangunan dan segala peralatan didalamnya. Unsur unsur hidup terdiri dari manusia (trisivitas), tumbuhan, binatang bahkan mikroorganisme. Keserasian antara berbagai unsur di kampus sangat menentukan produktivitas manusia yang hidup didalamnya. Salah satu aspek keserasian tersebut adalah kebersihan halaman. Tingginya perhatian managemen universitas terhadap keserasian lingkungan dikampus terlihat dari pembangunan arsitek dan lanskap kampus yang semakin baik dan serasi serta tersedianya sistim penanganan sampah. Namun demikian, sebagai besar sampah yang dihasilkan di ruang kampus masih dibuang ke tempat pembuangan sampah akhir. Untuk itu telah dilakukan suatu kegiatan kelompok mahasiswa pencinta alam FMIPA Universitas Sam Ratulangi dengan terlebih dahulu mengidentifikasi jenis tanaman penghasil daun utama di kampus universitas Sam Ratulangi Manado dan potensinya sebagai penghasil daun. Selanjutnya para mahasiswa telah dilatih untuk mengumpulkan sampah tersebut dan mengolahnya menjadi kompos. Hasil kegiatan ini menunjukan bahwa tanaman penghasil daun utama di kampus universitas Sam Ratulangi Manado adalah mahoni (Swietenia macrophylla King)) diikuti oleh angsana (Pterocarpus indicus Willd.), flamboyan (Delonix regia Raff) dan ketapang (Terminalia catapa). Tanaman mahoni mempunyai potensi untuk menghasilkan daun sebanyak 1 karung penuh dengan berat sekitar $2 \mathrm{~kg}$ per hari sedangkan pohon angsana menghasilkan daun kering yang lebih sedikit dibandingkan dengan daun mahoni.
\end{abstract}

Kata Kunci: sampah, zerowaste, kompos.

\begin{abstract}
The Sam Ratulangi University campus as a university space consists of physical and biological elements. The physical elements consist of air, buildings and all the equipment therein. The biological elements consist of humans (trisivities), plants, animals and even microorganisms. The harmony between the various elements on campus greatly determines the productivity of the people who live in it. One aspect of this harmony is the cleanliness of the yard. The very high attention of the university management towards the harmony of the campus environment can be seen from the construction of the architecture and the campus landscape which is getting better and more harmonious and the availability of a waste management system. However, most of the waste generated in campus spaces is still disposed of in landfills. For this reason, a program has been carried out by a group of students who love the nature and enviroment from the Faculty of Mathematics and Natural Sciences, Sam Ratulangi University by first identifying the types of main leaf-producing plants in the Sam Ratulangi University campus in Manado and their potential as a leaf
\end{abstract}


producer. Furthermore, the students have been trained to collect the waste and process it into compost. The results of this activity showed that the main leaf-producing plants at the Sam Ratulangi University campus in Manado were mahogany (Swietenia macrophylla King) followed by angsana (Pterocarpus indicus Willd.), Flamboyan (Delonix regia Raff) and ketapang (Terminalia catapa). Mahogany plants have the nost potential to produce and it can produce 1 full sack of leaves weighing about $2 \mathrm{~kg}$ per day while the angsana tree produces less dry leaves than mahogany leaves.

Keywords: waste, zerowaste, compost.

\section{PENDAHULUAN Analisa situasi}

Kampus Universitas Sam Ratulangi merupakan lokasi dimana trisivitasnya (dossen, tenaga kependidikan dan mahasiswa) hidup dan melakukan kegiatan sehari hari sesuai dengan fungsinya masing masing. Keadaan lingkungan di universitas ini semakin baik. Terlihat berbagai perbaikan penataan bangunan dan lanskape selama beberapa tahun belakangan ini sehingga menjadi lebih indah untuk dilihat dan nyaman untuk beraktivitas. Kampus Universitas Sam Ratulangi merapakan salah satu wilayah yang hijau di Kota Manado. Dari pengamatan citra satelit (Google Maps/Google Earth) terlihat bahwa kampus Unsrat memiliki ruang hijau yang dapat mencapai 5 persen.

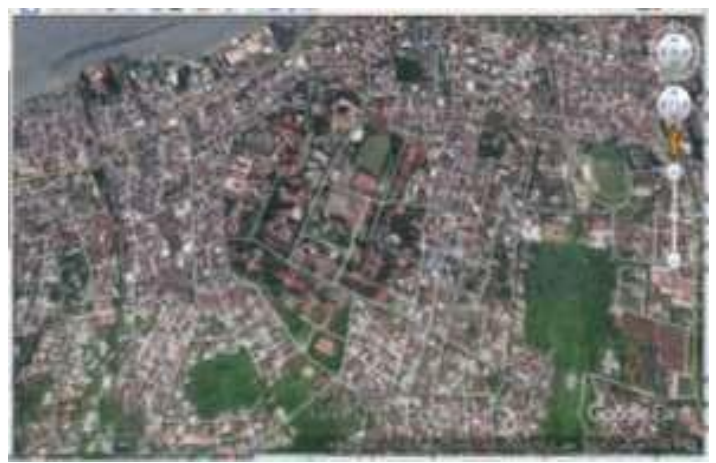

Gambar 1. Peta satelit kampus Universitas Sam Ratulangi Manado

Hal ini disebabkan oleh karena wilayah kampus ditumbuhi oleh oleh berbagai pohon besar maupun kecil (Gambar 1).
Penanganan sampah untuk kebersihan kampus telah ditangai dengan baik sejak beberapa tahun yang lalu. Pihak managemen universitas menyiapkan dana yang cukup untuk hal ini. Penganganan kebersihan lingkungan didalam ruangan gedung dan pengumpulan sampah di halaman Kampus Universitas Sam Ratulangi dilakukan oleh staf perusahan yang dikontrak oleh Universitas Sam Ratulangi. Penanganan sampah selanjutnya dilakukan oleh kelompok staf transportasi sampah dengan menggunakan truk untuk mengumpulkan sampah dan membawsanya ke tempat pembuangan akhir.

Hasil pengamatan secara sepintas menunjukan bahwa sebagian besar sampah yang terkumpul didalam truk merupakan daun tumbuhan. Hal ini disebabkan oleh karena banyaknya pepohonan yang terdapat di wilayah kampus. Namun demikian sampai saat ini belum diketahui secara tepat produksi daun dari pohon/tumbuhan yang ada di kampus Universitas Sam Ratulangi. Hasil pengamatan secara sepintas menunjukan bahwa setiap hari ada dua truk yang mengumpulkan sampah di kampus Universitas Sam Ratulangi. Bila setiap truk mengangkut sampah daun sebesar $50 \mathrm{~kg}$ maka dalam sehari dihasilkan sebanyak sekitar $100 \mathrm{~kg}$ sampah daun.

Produksi daun ditentukan oleh jenis tumbuhan dan ukuran kanopinya. Makin besar kanopinya makin besar produksi daunnya. Pengukuran kanopi daun dapat dilakukan dengan pengamatan dilapangan disertai dengan penggunaan citra satelit. 
Sampai pada saat ini penanganan sampah di Kampus Universitas Sam Ratulangi masih terbatas pada pengumpulan sampah di lingkungan kampus dan selanjutnya dibawa ke tempat pembuangan sampah akhir. Hal ini bukanlah suatu tindakan yang baik ditinjau berbagai sudut pandang. Pertama pembuangan sampah akan menambah permasalahan ruangan di tempat pembuangan sampah yang biasanya terbatas dibandingkan dengan sampah yang didatangkan. Kedua, transportasi sampah dari kampus ke tempat pembuangan akhir membutuhkan biaya sekurang kurangnya bahan bakar kendaraan. Ketiga, sampah khususnya yang berupa bahan organik dapat digunakan untuk berbagai produk yang bermanfaat bagi manusia.

Sampah dari kampus Universitas Sam Ratulangi yang sebagian besar adalah daun tumbuhan dapat digunakan untuk pembuatan kompos. Kompos adalah bahan hasil pengolahan bahan tumbuhan dan binatang melalui proses fermentasi yang digunakan untuk bahan pupuk. Penggunaan kompos sebagai pupuk mempunyai berbagai kelebihan dari pupuk buatan disebabkan

oleh karena kompos akan memperbaiki sistim biologi dan daya serap air dari tanah yang sangat menopang pertumbuhan tanaman disamping mempunyai unsur haru yang cukup dan dapat diproduksi dengan lebih murah.

Teknologi pembuatan sampah telah dilaporkan diberbagai media baik ilmiah, mass media maupun internet. Pada prinsimnya pembuatan kompos dilakukan secara alami maupun dengan menggunakan bahan organik seperti daun atau penambahan mikroorganisme dan penambahan bahan lainnya seperti tanah dan pupuk kandang.

Suasana kehidupan diluar ruangan di kampus Universitas Sam Ratulangi belum diiringi dengan penataan ruangan di dalam gedung. Sekalipun beberapa ruangan telah mempunyai dekorasi yang cukup tetapi kebanyakan ruang masih dibiarkan kosong. Penataan ruangan ruangan ini akan lebih nyaman bila ditempatkan tanaman hias. Tanaman hias tidak saja menciptakan ruangan lebih indah tetapi juga memberikan rasa segar dan nyaman. Namun demikian pengadaan tanaman hias serta bahan untuk pemeliharaannya sangat terbatas. Salah satu keterbatasan tersebut adalah tidak adanya suplai media tumbuh (tanah), tanaman hias dan pupuk organik untuk pemeliharaannya.

Kehidupan para dosen dan tenaga kependidikan di kampus Universitas Sam Ratulangi pada umumnya berada dalam strata menengah sampai menengah atas dalam kehidupan masyarakat di Kota Manado. Mereka mempunyai kemampuan membeli berbagai hal khususnya untuk meningkatkan status kehidupan dalam masyarakat maupun untuk menata lingkungan rumah mereka sehingga semakin indah, segar dan nyaman.

Dari uraian diatas terlihat bahwa potensi kebutuhan kompos di kampus Universitas Sam Ratulangi cukup besar, namun demikian sampai pada saat ini belum tersedia. Di pihak lain pengolahan sampah di lingkungan Universitas Sam Ratulangi masih belum maksimal. Sebagai lembaga pendidikan tinggi, tentunya Universitas Sam Ratulangi haruslah selalu terdepan dalam segala hal, termasuk pengelolaan lingkungannya. Mahasiswa program studi kimia yang mempelajari tentang biokimia tentunya mempunyai kesadaran yang tinggi terhadap hasil proses fotosintesa yang masih belum termanfaatkan dengan sebaik baiknya. Mereka mengetahui produk proses alami ini adalah sesuatu yang seharusnya menjadi bermanfaat bagi manusia dan tidak dibuang saja ke tempat pembuangan sampah.

\section{Permasalahan Mitra}

Mahasiswa sebagai pokok utama dari kegiatan pendidikan tinggi di Universitas Sam Ratulangi masih mempunyai keterbatasan dalam memanfaatkan ilmu pengetahuan mereka untuk memproduksikan sesuatu yang dapat 
menghasilkan uang. Sebagian dari mahasiswa Program Studi Kimia tergabung dalam Kelompok Mahasiswa Pencinta Lingkungan. Kelompok ini pada umumnya terdiri dari mahasiswa yang mengambil mata kuliah biokimia dan analisa kimia. Kelompok ini mempunyai minat untuk meningkatkan kehidupan manusia dengan memperbaiki pengololaan lingkungan khususnya yang berhubungan dengan pengelolaan sampah. Permasalahannya adalah mereka belum mampu melihat kemungkinan pemanfaatan ilmu yang telah mereka dalami sebagai aktivitas usaha yang dapat mendatangkan pendapatan sekaligus peningkatan pengelolaan lingkungan. Salah satunya adalah usaha pendugaan produksi, pengumpulan sampah daun dilingkungan kampus, penentuan kualitas kimia bahan sampah dan pengolahannya menjadi siap untuk bahan baku pembuatan kompos. Kegiatan ini tidak saja dapat menghasilkan pendapatan bagi mereka tetapi juga akan meningkatkan kelestarian alam dengan memanfaatkan sampah yang kelihatannya tidak berguna lagi bahkan menjadi beban bagi universitas. Kegiatan ini merupakan juga tanggung jawab mereka dalam mencari solusi terbaik bagi persoalan kerusakan lingkungan serta memperbaiki suasana fisik di ruang ruang terbuka di kampus.

Teknologi pengolahan sampah daun telah berkembang cukup jauh. Namun demikian para mahasiswa biasanya masih terbatas untuk melihat berbagai kemungkinan penggunaan ilmu yang telah mereka peroleh dalam bentuk teknologi yang dapat digunakan dalam kehidupan sehari hari. Usaha pengumpulan sampah dan pengolahannya menjadi bahan baku yang siap diolah menjadi sampah membutuhkan peralatan, sarana ruangan dan biaya analisa kimia. Keterbatasan finansial mereka perlu didukung untuk dapat menjadikan ide-ide mereka menjadi kenyataan.

Aspek lain yang diperlukan oleh mahasiswa adalah kemampuan mengelolah kegiatan pengolahan sampah menjadi kompos. Kegiatan ini merupakan suatu kegiatan yang selalu melibatkan banyak orang. Untuk itu managemen kegiatan perlu dilakukan dengan baik meliputi organisasi dan pembagian kerja, perencanaan, pelaksanaan dan evaluasi. Mahasiswa biasanya masih kurang kemampuan dalam melakukan semua kegiatan ini.

Kelemahan para mahasiswa ini adalah keadaan finansial mereka masih sangat terbatas dan kebanyakan masih tergantung pada orang tua mereka. Demikian juga dengan teknik produksi, pengumpulan dan analisa kimia bahan sampah mereka masih terbatas. Dipihak lain, mereka dituntut untuk mampu mendapatkan ide-ide untuk memanfaatkan ilmu yang mereka telah pelajari bagi kehidupan mereka dan bagi kehidupan masyarakat disekitar mereka.

\section{Target}

Dari uraian pada sub bab permasalahan mitra, telah diidentifikasi tiga permasalahan utama yang dihadapi mitra (kelompok mahasiswa) yaitu: teknik penerapan ilmu yang mereka telah pelajari menjadi kegiatan usaha untuk produksi, kemampuan managemen kegiatan dan keterbatasan permodalan. Sebagai solusi permasalahan pertama yaitu "teknik penerapan ilmu yang mereka telah pelajari menjadi kegiatan usaha untuk produksi" maka perlu diberikan bimbingan dan pengarahan tentang berbagai dasar pengetahuan kimia yang dijadikan teknologi yang tersedia untuk pengolahan sampah. Materi ini akan diambil dari berbagai publikasi ilmiah seperti Budihardjo (2006) dan Yuwono, et. al. (2013), buku petunjuk praktis seperti Suwahyono, (2014) maupun majalah online seperti Hennessy (2017).

Solusi permasalah kedua yaitu keterbatasan kemampuan managemen akan diatasi dengan melakukan pelatif managemen. Pelatihan ini akan meliputi prinsip prinsip perencanaan, organisasi, pelaksanaan, administrasi keuangan dan evaluasi. Pelatihan managemen ini akan ditambah lagi dengan berbagai teknik 
pemasaran produk kompos.

Solusi permasalahan ketiga yaitu keterbatasan finasial akan dilakukan dengan bantuan pembuatan ruang penampungan bahan yang sederhana serta pembelian kantung kantun pengumpulan sampah.

Kegiatan pembuatan sampah ini akan dilakukan dengan bekerjasama dengan Kelompok Mahasiswa Pencinta Lingkungan Program Studi Biologi. Kelompok mahasiswa yang terakhir ini akan menangani pencampuran bahan baku daun dengan tanah, pupuk kandang dan biakan mikroorganisme (EM4).

Sebagai luaran dari kegiatan ini ada dua yaitu pertama adalah sistim usaha pengumpulan dan penyiapan sampah daun menjadi bahan baku pembuatan kompos. Luaran kedua adalah bahan baku untuk proses pembuatan kompos.

\section{METODE PELAKSANAAN}

Mitra kegiatan pelaksanaan pengabdian pada masyarakat ini adalah mahasiswa Program Studi Kimia yang tergabung dalam Kelompok Pencinta Lingkungan. Mahasiswa akan memberikan waktu mereka diluar jam perkuliahan untuk melakukan berbagai kegiatan usaha pembuatan kompos, budidaya tanaman hias dan penjualan tanaman hias. Kegiatan ini akan digabungkan dengan kegiatan Kelompok Mahasiswa Pencinta Lingkungan Fakultas MIPA. Mahasiswa Program Studi Kimia akan melakukan kegiatan pendugaan potensi daun sebagai bahan baku kompos, pengumpulan sampah daun, dan analisa kimia daun dan kompos untuk penentuan kualitas bahan.

Mitra MPA Scientist dan Himakim dipandu oleh Tim PKM akan melakukan kegiatan- kegiatan ini::

1. Pelatihan teknik perhitungan produksi biomasa daun yang akan dilakukan dengan menggunakan citra satelit (Google Earth) dan pengukuran besarnya tajuk dilapangan. Sebagai outputnya adalah data ilmiah tentang potensi produksi sampah daun di Kampus Universitas Sam Ratulangi.

2. Pelatihan teknik pengumpulan sampah yang akan melibatkan staf kebersihan Universitas Sam Ratulangi.

3. Pelatihan pengolahan sampah daun menjadi siap untuk bahan baku [pembuatan kompos.

4. Pelatihan analisa kimia dari sampah daun dan kompos.

5. Pelatihan managemen pengolahan usaha. Sebagai outputnya adalah struktur organisasi unit usaha (pembagian tugas; tdermasuk untuk bekerjasama dengan unit penanganan sampah Universitas Sam Ratulangi dan tenaga kerja upahan yang akan membantu melakukan berbagai pekerjaan seperti pembalikan tumpukan kompos), rencana kegiatan secara terinci dengan pos-pos pembiayaan dan jadwal. Kegiatan ini untuk menyelesaikan permasalahan yang dihadapi mitra (mahasiswa) yang masih mempunyai keterbatasan managemen.

6. Pelatihan teknik penjualan tanaman hias dalam pot. Kegiatan ini untuk menyelesaikan keterbatasan mitra (mahasiswa) dalam teknik teknik pemasaran.

Kedua jenis kegiatan terakhir diatas (poit 5 dan 6) akan dilakukan bersama sama dengan Kelompok Pencinta Lingkungan Fakultas MIPA. Evaluasi kegiatan akan dilakukan secara kontinyu oleh karena Tim Pelaksana yang terus berada di Kampus. Pada akhir kegiatan dimana proses produksi telah selesai, mahasiswa akan terus melaksanakan kegiatan ini sesuai dengan sistim organisasi mahasiswa untuk dilanjutkan oleh mahasiswa lain pada tahun ajaran yang berikutnya. Keuntungan usaha akan menjadi milik dari organisasi mahasiswa baik untuk pengembangan lebih besar lagi dari usaha ini atau kegiatan kegiatan lain yang disetujui oleh organisasi mahasiswa program studi.

$$
\text { Pengalaman yang diperoleh }
$$


mahasiswa yang terlibat dalam kegiatan ini akan merupakan output lain bagi kegiatan ini yang diharapkan para mahasiswa dapat mengembangkan usaha seperti ini di tempat lain atau kegiatan usaha lain yang mirip dengan usaha ini.

\section{HASIL DAN LUARAN YANG DICAPAI}

Pengumpulan sampah daun di kampus Universsitas Sam Ratulangi telah dilakukan dengan bekerjasama dengan Bagian Kebersihan Kampus. Pengumpulan dilakukan oleh petugas kebersihan dengan memperlengkapi mereka dengan karung plastik yang telah dimodofokasi sehingga memudahkan penanganan. Karung karung yang telah berisi sampah daun kering dimuat dalam truk sampah dan didrop ditempat pengolahan kompos.

Jenis daun yang banyak dikumpulkan adalah dari tanaman mahoni (Swietenia macrophylla King)) diikuti oleh angsana (Pterocarpus indicus Willd.), flamboyan (Delonix regia Raff) dan ketapang (Terminalia catapa). Dibeberapa tempat di kampus Unsrat, tanaman mahoni keban yakan ditanam secara rapat dengan jarak tanam sekitar $4 \times 4$ meter, sedangkan tanaman angsana ditanam dalam pola seperti barisan disamping jalan jalan. Kebanyakan tanaman mahoni telah mempunyai diameter batang sekitar 40 sampai $60 \mathrm{~cm}$, sedangkan pohon mahoni mempunyai diameter sekitar 30 sampai 40 $\mathrm{cm}$. Tinggi tanaman berkisar pada 8 sampai 12 meter. Daun pohon mahoni lebih tebal dan kaku dibandingkan dengan pohon angsana. Tanaman mahoni mempunyai potensi untuk menghasilkan daun sebanyak 1 karung penuh dengan berat sekitar $2 \mathrm{~kg}$ per hari. Pohon angsana menghasilkan daun kering yang lebih sedikit dibandingkan dengan daun mahoni.

Pada tahapan ini telah dibuat peralatan penghancuran daun kering seperti pada Gambar betikut. Mesin ini menggunakan motor diesel untuk menggerakan pisau oisau pemotong didalamnya. Daun kering akan masuk ke mesin penghancur yang akan memotong daun menjadi potongan potongan kecil. Tujuan pemotongan dimaksudkan untuk membuat daun hancur sehingga luas permukaan daung yang terluka akan lebih besar. Hal ini akan mempercepat mikroorganisme menghancurkan daun tersebut.

Suatu teknologi baru sedang dikembangkan dalam usaha konservasi karbon yang terikat sambil memperbaiki tingkat kesuburan tanah. Teknik ini dinamakan arang bio atau "bio-charcoal". Trknologi ini sangat sesuai dipadukan dengan penggunaan kompos akrena dapat memperbaiki kehidupan mikroorganisme dalam kompos sementara memperahankan nutrisi dalam kompos.

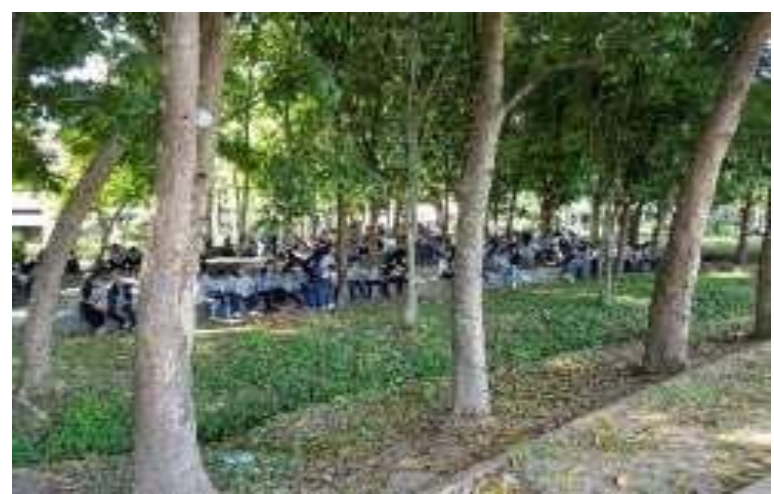

Gambar 2. Populasi pohon mahoni di depan Fakultas MIPA.

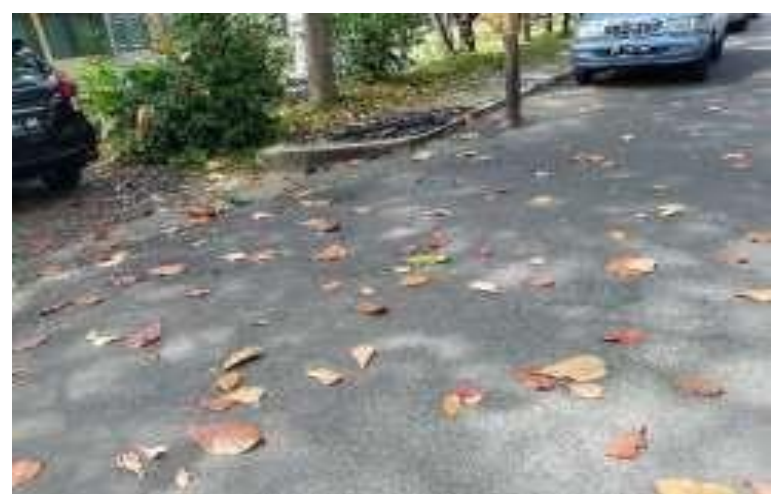

Gambar 3. Sampah daun campuran di depan Fakultas MIPA. 


\section{Jurnal Perempuan dan Anak Indonesia}

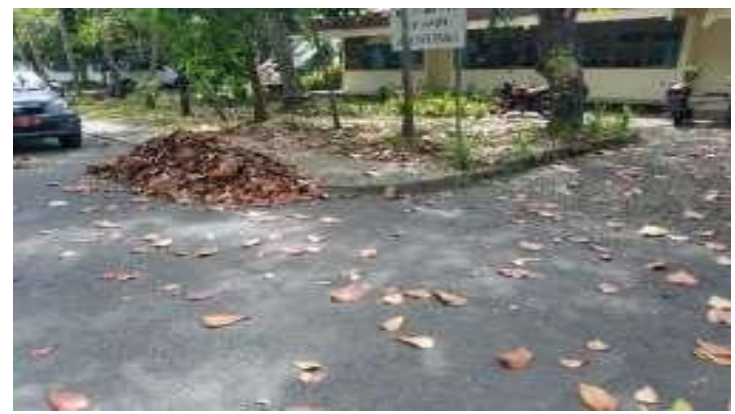

Gambar 4. Pengumpulan sampah daun campuran di depan Fakultas MIPA.

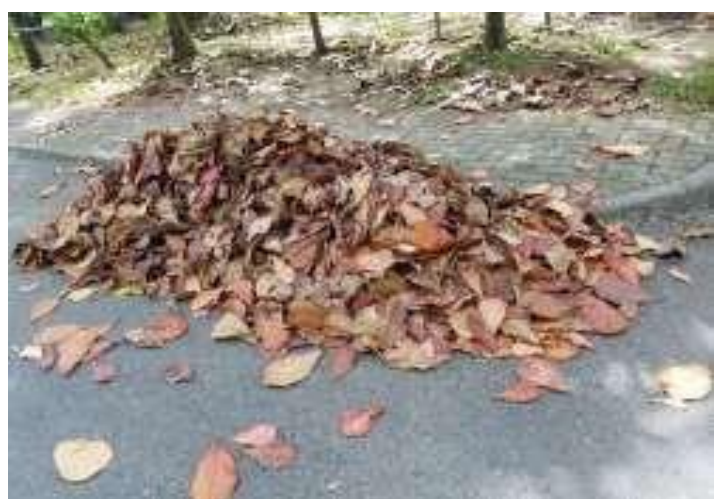

Gambar 5. Pengumpulan sampah daun campuran di depan Fakultas MIPA.

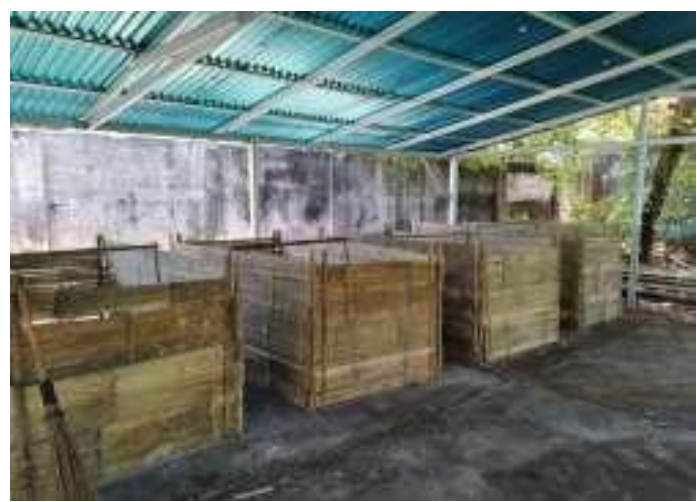

Gambar 6. Tempat pengomposan yang dibuat dari bambu.

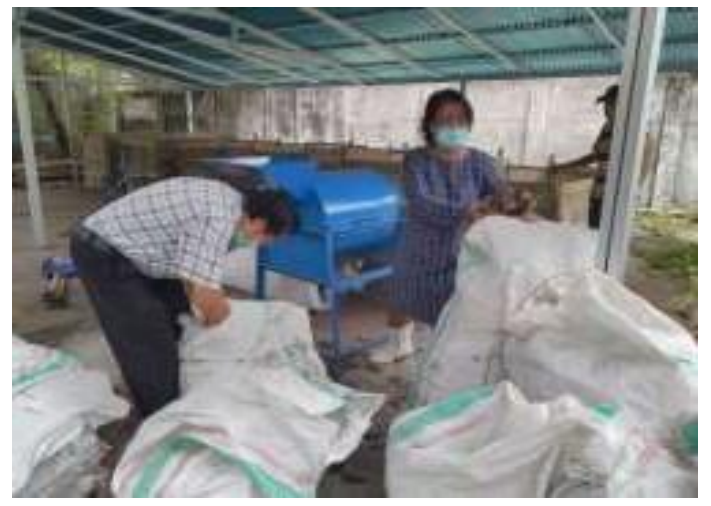

Gambar 7. Sampah daun yang dikumpulkan dalam karung

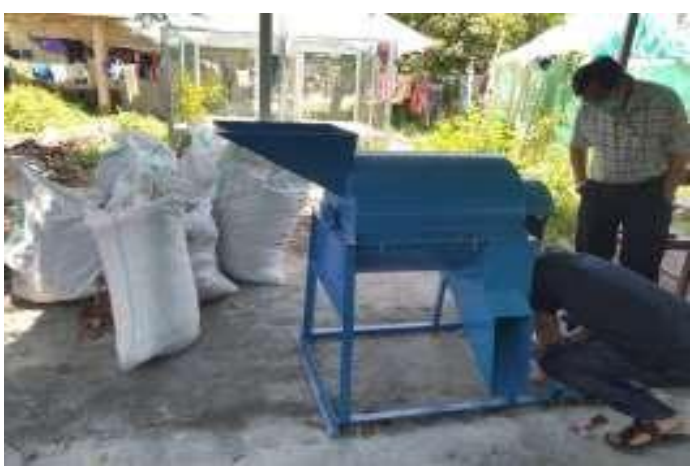

Gambar 8. Alat pencacah daun kering.

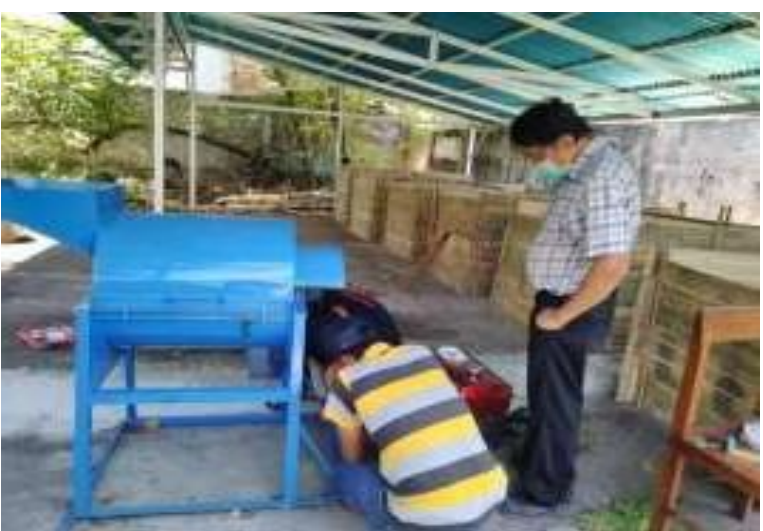

Gambar 9. Pengaturan mesin penggerak penghancur sampah.

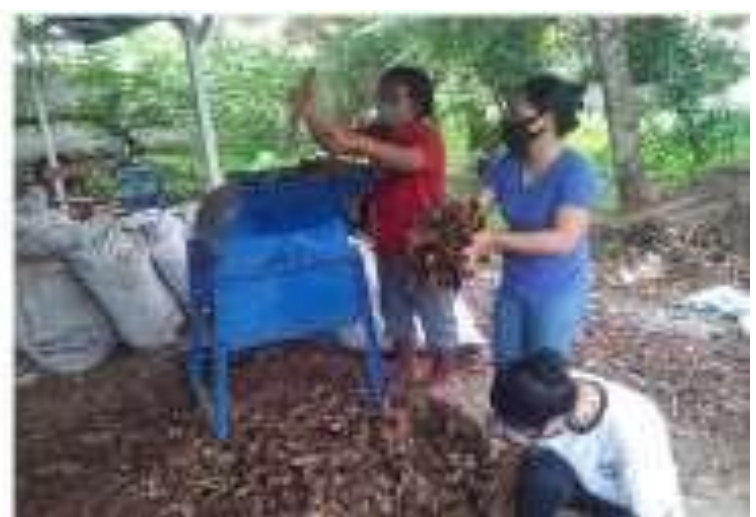

Gambar 10. Penghancuran daun kering dengan mesin pencacah oleh dosen pembimbing dan mahasiswa.

Demikian juga dengan pembuatan bagunan tempat pembuatan kompos dan kotak kompos dari bambu. Mahasiswa yang terlibat dalam kegiatan ini telah memahami proses pembuatan kompos dari sampah daun kering, yang selanjutnya akan diarahkan untuk menjadikannya sebagai usaha tanaman hias.

\section{KESIMPULAN DAN SARAN}

Pengumpulan sampah daun tanaman di area Kampus Unsrat telah dapat dilakukan. 
Selanjutnya sampah tersebut diolah menjadi menjadi kompos dengan terlebih dahulu dihancurkan dengan mesin pencacah daun. Produk ini telah digunakan untuk produksi tanaman hias dalam wadah pot. Kegiatan ini perlu dilanjutkan bagi mahasiswa angkatan lain dan perlu diperluas dengan teknologi pembuatan arang bioaktif yang dapat menyimpan produk taman dalam benuk sampah kayu menjadi terikat secara lestari dan sekaligus membantu mempertahankan kesuburan tanah tempat tumbuh tanaman pot.

\section{DAFTAR PUSTAKA}

Budiharjo, M.A. 2006. Studi Potensi Pengomposan sampah Kota Sebagai Salah Satu Alternatif Pengelolaan Sampah di TPA Dengan Menggunakan Aktivator EM4 (Effective Microorganism. Jurnal PRESIPITASI. 1 (1): 25-31.

Yuwono, S.A., N. Ichwan, dan S.K. Saptomo. 2013. Implementasi Konsep "Zero Waste Production Management" Bidang Pertanian: Prngomposan Jerami Padi Organik dan Pemanfaatannya. Jurnal Bumi Lestari,n13 (2):366-373.

Hennessy, R. 2017. How to Add Urea to compost. Garderning Guides.Com. September 21.

Suwahyono, U. 2014. Cara Cepat Buat Kompos Dari Limbah. Penebar Swadaya. Jakarta. 